\title{
INDIVIDUAL FACTORS OF EXTENDING THE WORKING LIFE FOR PEOPLE WITH DISABILITIES IN POLAND
}

\section{Justyna Wiktorowicz}

University of Lodz, Department of Economic and Social Statistics, Lodz, Poland e-mail: justyna.wiktorowicz@uni.lodz.pl

ORCID: 0000-0001-9246-9225

\section{Lukasz Ziarko}

University of Lodz, Department of Economic and Social Statistics, Lodz, Poland e-mail: lukasz.ziarko@uni.lodz.pl

ORCID: 0000-0002-9726-5552

\section{(C) 2020 Justyna Wiktorowicz, Łukasz Ziarko}

This work is licensed under the Creative Commons Attribution-ShareAlike 4.0 International License. To view a copy of this license, visit http://creativecommons.org/licenses/by-sa/4.0/

Quote as: Wiktorowicz, J. and Ziarko, Ł. (2020). Individual factors of extending the working life for people with disabilities in Poland. Econometrics. Ekonometria. Advances in Applied Data Analysis, 24(4).

DOI: 10.15611/eada.2020.4.01

JEL Classification: J21, J26

\begin{abstract}
Extending working life is an important challenge for modern economies. In Poland, 40\% of people aged 50-64 are economically inactive. In the population of people with disabilities, this percentage is much higher $(78 \%)$. The aim of this paper is to assess the individual factors for extending the working life of Poles aged 50-64 and their comparison between people with and without disabilities. The empirical analysis is based on the national survey, Social Diagnosis (for people aged 50-64). The analysis was carried out with the application of logistic regression, as well as the Student t-test, the Mann-Whitney test, the chi-squared test of independence. The logistic regression results show that the factors of extending working life for people with disabilities are different than for others - statistically significant determinants are formal outcomes of human capital development (regarding individuals without disabilities, the list of factors extending working life is more extensive).
\end{abstract}

Keywords: economic activity, extending working life, disability, logistic regression.

\section{Introduction}

Extending working life is an important challenge for modern economies, and this also applies to Poland. Despite the increase in the activity and employment rates of people aged 50+, four out of ten Poles aged 50-64 are economically inactive. At the 
same time, economic activity is lower among women than men. This fact is related to the lower statutory retirement age for women (60 years), as opposed to men (65 years). However, the list of occupational deactivation factors is much longer, and institutional conditions are important, even though they are not the only factors determining the moment of retirement, many of them are individual. Research shows (Wiktorowicz, 2016) that individual factors turn out to be even more important than institutional or organisational ones. In the subject literature, the discussed factors are rarely assessed concerning people with disabilities. Therefore the aim of the study is the assessment of the individual factors of extending the working life of Poles aged 50-64 and the comparison between people with and without disabilities. The social and human capital of individuals, as well as socio-economic factors, are the area of interest.

\section{Extending working life determinants - literature review}

In the literature on the subject, working life is usually examined using the concept of push and pull factors, i.e. those pushing people out of the labour market and pulling them into economic inactivity (Funk 2004; Phillipson and Smith 2005; van Oorchot and Jensen 2009; Walker 1985). The pull factors are embedded in the pension system. The traditional mechanism of social transfers, where the amount of pension benefits does not depend on the length of service, discourages the economic activity of older people. The primary factors pulling people aged $50+$ into economic inactivity include: a prolonged period of collecting unemployment benefits by older people, easier exit from the labour market for older people who can opt for early retirement, the qualification system for a disability benefit, the possibility of continuing work despite early retirement (Funk, 2004). Among the push factors are: collective employment agreements which provide particular security for older people; legal provisions obliging employers to pay compensation for the dismissal of older employees; seniority wages; growing expectations related to employee qualifications caused mainly by the development of modern technologies and globalisation; the decreased flexibility of employees due to the advancing age of the workforce (Funk, 2004; Zwick, 2012). Ageism and the related stereotypical views of older employees also have a prominent place among the push factors (Krzyżowski, 2011), as do career opportunities for them offered on the local labour market (when the labour market situation is generally difficult, older employees are going to prefer retirement (van Oorschot and Jensen 2009)). An important push factor is also the economics of human resource policies in companies (Jurek, 2012), especially delays in implementing age management. De Preter, Van Looy, and Mortelmans (2013) list two subgroups among the pull and push factors: the institutional factors subgroup and the individual factors subgroup. Hofäcker (2015) supplements this classification, identifying: 
1) institutional determinants: pull, push and stay factors (the stay factors include an active ageing policy - Active Labour Market Policy and lifelong learning),

2) company-level determinants,

3) individual determinants.

Taking into consideration the individual factors of extending working life, it should be emphasised that one of the most important is poor health and the accompanying difficulties limiting one's ability to work (see e.g. Aaron and Callan, 2011; Barnes, Parry, and Taylor, 2002; Clark, Ogawa, Lee, and Matsukura, 2008; Humphrey, Costigan, Pickering, Stratford, and Barnes, 2003; Kryńska, Krzyszkowski, Urbaniak, and Wiktorowicz, 2013; Lis and Magda, 2014; McNair, Flynn, Owen, Humphreys, and Woodfield, 2004; Naegele and Bauknecht, 2013; Whiting, 2005). The probability of deactivation grows with age and seniority. The place of residence, which is related to the availability of job offers (Phillipson and Smith, 2005; Wiktorowicz, 2014), as well as gender and marital status are also of importance. In most countries the retirement age for women is lower than for men, therefore an analysis of the probability of retirement for people in productive age shows that the risk is higher in the case of women. Men are more likely to be economically active even after 50, although women are catching up with them (Silcock, 2013). However, women are under pressure to stay unemployed when they do housekeeping, take care of their home, children or sick people, which encourages their earlier work inactivation (Contreras, Martellucci, and Thum, 2013; Kryńska et al., 2013). Older people who were married or cohabiting were also more likely to be economically active than single people. Whiting (2005) proved that older workers who live in relationships, are more likely to continue their economic activity than singles. The partner's or another dependant's poor health necessitates undertaking caring duties, which may push the carer out of the labour market (van Solinge and Henkens, 2007). The financial situation of the household is also important. On the one hand, a good financial situation encourages people to become economically inactive so they can find time to fulfil their dreams, spend time with the family, etc. On the other hand, a bad financial situation may encourage them to stay economically active (another pull factor for jobseekers (De Preter et al., 2013). Some people work until they reach or exceed the retirement age because they like their jobs, feel fulfilled in their careers or view their jobs as a way to remain socially active. Yet many people continue to work only due to financial reasons or a feeling that they cannot afford to retire (Silcock, 2013; Gustman and Steinmeier, 2005).

The importance of human capital which, above all, includes the level of education, competencies and state of health as underlined earlier, is corroborated by, among others, Hofäcker's studies (2015). Higher competencies and education level are conducive to prolonging economic activity (see e.g. Gurria, 2008; Khan, Rutledge, and Wu, 2014; Kryńska et al., 2013; Maltby, 2011; McNair, Flynn, Owen, Humphreys, and Woodfield, 2004; Silcock, 2013; Sinclair, Watson, and Beach, 2013; Smeaton and McKay, 2003; Whiting, 2005), and this is why raising qualifications 
has been the key direction in the active ageing policy within the economic activity. A higher education level contributes to continuing work after reaching the retirement age (McNair et al., 2004). The risk of early retirement is, in turn, higher for people who do not participate in lifelong learning; professional training is also an important strategy to keep the older people in employment (De Baets and Warmoes, 2012). The main problem in the context of the further employment of older workers is the "devaluation" of competencies rather than the ageing in itself. ICT competencies still seem to be a gap in older people's development (Hashim and Wok, 2011).

Social capital, as well as networks developed during a long professional career, comprise significant factors here - they may compensate for the possible decrease in productivity, especially in the period preceding deactivation. In unitary terms, social capital is understood as resources that an individual can mobilise through networks of personal connections. Three components are usually distinguished within the framework of social capital - networks, trust and norms (see e.g. Paxton, 1999). Overall, it plays a special role in creating human capital (and vice versa), and its status is particularly emphasised when it comes to those eager to find or change jobs, as well as to employees in the context of their career development. At the stage of seeking employment, neither trust or norms seem as significant as networks (Stone, Gray and Hughes, 2003).

\section{Data and methods}

The empirical analysis is based on the representative Social Diagnosis national survey (Social Diagnosis, 2015). The survey was conducted periodically at two-year intervals - the last edition took place in 2015. It comprises a nationwide survey, representative both nationally and individually. The sample covered a total of 22,220 people aged $16+$ and reflects the structure of the population in terms of age, gender, educational level, size and place of residence, and their voivodeship. The population analysed in this paper comprised people aged $50+$, but still in the productive age (i.e. for people aged 50-64; $n=5728$ ).

The statistical analysis was carried out using basic statistical tests applied to compare the populations, in particular the chi-square independence test (or alternatively Fisher's exact test), the Student t-test and the Mann-Whitney test. The analysis was also carried out with the application of the logistic regression (this method is widely discussed in, e.g. Hosmer, Lemeshow, and Sturdivant, 2013) which formed the basis for the estimation of the economic activity function for people aged 50-64 - separately for persons with and without disabilities, as well as for groups distinguished based on the level of disability. Verification of economic activity was based on a question about current status on the labour market. The output variable (Economic Activity Status, EAS) was a binary variable, with 1 for economically active people (employees, self-employed, farmers and the unemployed (Kołodziejczak, 2018)), and 0 for economically inactive. As exploratory variables, individual factors 
listed in the earlier paragraph were proposed. First of all, demographic features and different measures of human and social capital were used - gender, age (5-year age groups), size of place of residence, family characteristics - having children (variable parents), marital status, as well as income - current and that expected in two years' time. Measures of human capital were: level of education, $W W I$ variable (continuous) means the range of Internet usage, i.e. the number of activities involving Internet usage (values from 0 to 26), as well as five binary variables: driving licence, the use of foreign languages, computer usage, Internet usage, and educational activity (in the last two years). Social capital was measured using the size of social networks. Taking into consideration the fact that the analysis concentrated on people with disabilities, measures of health (one of the indicators of human capital) were omitted in the models. The logistic regression models were considered correct if: (1) in the omnibus test of model coefficients, verified hypothesis $\mathrm{H}_{0}: \beta_{1}=\beta_{2}=$ $\ldots=\beta_{k}=0, \mathrm{H}_{1}: \sim \mathrm{H}_{0}$ (Szymczak, 2010, s. 172; Menard, 2002, p. 22), $p<\alpha,(2)$ Nagerkelke's pseudo $\mathrm{R}^{2}$ is relatively high (Maddala, 1983, p. 40), (3) counting determination measure is relatively high (Gruszczyński, 2012, p. 91), in particular, the percentage of correct qualifications for $y=1$ is high. Due to the inclusion of qualitative variables, the Hosmer-Lemeshow test was omitted. In the assessment of the significance of the relation for each or independent variable, the Wald test (Hosmer et al., 2013, p. 14) was used. The odds ratio (OR, $\operatorname{exp(B))~was~used~to~}$ assess how the probability of success (being economically active) changes when the independent variable increases (or how this probability differs in the study group in comparison to the reference one) (Sweet and Grace-Martin, 2003, p. 161). The study adopted the standard significance level $\alpha=0.05$. The calculations were performed in PS IMAGO SPSS.

\section{Economic activity of Poles with disabilities}

In Poland, in the population aged 50-64, people with disabilities represent $16 \%$. Their economic activity is low - in 2015 , only $22 \%$ of Poles with disabilities in this age group were economically active (in the population without disabilities this percentage was $67 \%$ ).

The economic activity of people with disabilities aged 50-64 is not significantly related to gender $(p=0.717-$ Table 1$)$ and marital status $(p=0.634)$. Economically active people come more often from younger aged sub-groups. In the 50-64 sub-group, they number $32 \%$, while in the $60-64-23 \%$ (nearly half of the professionally inactive people are 60-64). Indeed, economically active individuals occur significantly more often among people with disabilities aged 50-64 who have children (30\%), live in large cities $(35 \%)$, or with a lower degree of disability ( $38 \%$ of professionally active have a mild disability, and only $8 \%$ have severe disability level). Economically active people with disabilities have a higher income - the current one in 2015 (median 350 USD for those active vs 238 USD for those inactive) and the expected one 
(median 450 USD for people with disabilities which are active vs 275 USD for those inactive), see Table 1.

Table 1. People with disabilities - comparison of demographic features in the subpopulation of economically active and inactive Poles aged 50-64

\begin{tabular}{|c|c|c|c|}
\hline \multirow{2}{*}{\multicolumn{2}{|c|}{ Variables }} & \multicolumn{2}{|c|}{ Economically } \\
\hline & & \multirow{3}{*}{$\begin{array}{c}\text { active }(n=209) \\
46 \% \\
54 \%\end{array}$} & \multirow{3}{*}{$\begin{array}{c}\text { inactive }(n=722) \\
48 \% \\
52 \% \\
\end{array}$} \\
\hline Gender $(p=0.717)$ & women & & \\
\hline & men & & \\
\hline \multirow[t]{3}{*}{ Age $\left(p<0.001^{*}\right)$} & $50-54$ & $32 \%$ & $19 \%$ \\
\hline & $55-59$ & $45 \%$ & $32 \%$ \\
\hline & $60-64$ & $23 \%$ & $48 \%$ \\
\hline \multirow{3}{*}{$\begin{array}{l}\text { The size of the place of residence } \\
\left(p=0.008^{*}\right)\end{array}$} & rural area & $29 \%$ & $38 \%$ \\
\hline & small or medium town & $35 \%$ & $36 \%$ \\
\hline & the city & $35 \%$ & $25 \%$ \\
\hline \multirow[t]{2}{*}{ Parents $(p=0.007 *)$} & yes & $30 \%$ & $21 \%$ \\
\hline & no & $70 \%$ & $79 \%$ \\
\hline \multirow[t]{2}{*}{ Marital status $(p=0.634)$} & married & $68 \%$ & $70 \%$ \\
\hline & others & $32 \%$ & $30 \%$ \\
\hline \multirow[t]{3}{*}{ Disability level $\left(p<0.001^{*}\right)$} & severe & $8 \%$ & $22 \%$ \\
\hline & moderate & $54 \%$ & $52 \%$ \\
\hline & mild & $38 \%$ & $27 \%$ \\
\hline \multirow[t]{2}{*}{ Monthly income $\left(p<0.001^{*}\right)$} & mean (USD) & 413 & 280 \\
\hline & median (USD) & 350 & 238 \\
\hline \multirow{2}{*}{$\begin{array}{l}\text { Expected monthly income } \\
\text { in } 2 \text { years }\left(p<0.001^{*}\right)\end{array}$} & mean (USD) & 523 & 335 \\
\hline & median (USD) & 450 & 275 \\
\hline
\end{tabular}

$p$ - probability in the chi-squared test of independence, the Mann-Whitney test or the Student $t$-test; $*$ - differences statistically significant $(\alpha=0.05)$.

Source: own calculations based on the (Social Diagnosis, 2015), individual data.

Economically active people with disabilities aged 50-64 have a higher level of human and social capital that those inactive (Table 2). The share of people with a higher level of education amongst the active subpopulation is $12 \%$ (as compared to only $5 \%$ in the inactive one). Economically active people were much more active educationally during the last two years than the economically inactive $(10 \%$ vs $1 \%)$. They are more likely to be able to use computers and the Internet (53\%-54\% vs 33\%-34\% for the inactive), and their range of Internet usage is wider (on average, they use 6.3 solutions available on the Internet from the 26 taken into consideration, although half of them use no more than two solutions; 
Table 2. People with disabilities - comparison of selected features of human and social capital in the sub-population of economically active and inactive Poles aged 50-64

\begin{tabular}{|c|c|c|c|}
\hline \multirow{2}{*}{\multicolumn{2}{|c|}{ Variables }} & \multicolumn{2}{|c|}{ Economically } \\
\hline & & active $(n=209)$ & inactive $(n=722)$ \\
\hline $\begin{array}{l}\text { Level of education } \\
\left(p=0.001^{*}\right)\end{array}$ & $\begin{array}{l}\text { lower secondary or below } \\
\text { vocational } \\
\text { secondary } \\
\text { higher }\end{array}$ & $\begin{array}{l}19 \% \\
44 \% \\
25 \% \\
12 \% \\
\end{array}$ & $\begin{array}{r}24 \% \\
42 \% \\
30 \% \\
5 \% \\
\end{array}$ \\
\hline $\begin{array}{l}\text { Driving license } \\
(p=0.072)\end{array}$ & $\begin{array}{l}\text { yes } \\
\text { no }\end{array}$ & $\begin{array}{l}53 \% \\
47 \%\end{array}$ & $\begin{array}{l}46 \% \\
54 \%\end{array}$ \\
\hline $\begin{array}{l}\text { Educational activity in last } \\
2 \text { years }\left(p<0.001^{*}\right)\end{array}$ & $\begin{array}{l}\text { yes } \\
\text { no }\end{array}$ & $\begin{array}{l}10 \% \\
90 \%\end{array}$ & $\begin{array}{r}1 \% \\
99 \%\end{array}$ \\
\hline $\begin{array}{l}\text { Computer users } \\
\left(p<0.001^{*}\right)\end{array}$ & $\begin{array}{l}\text { yes } \\
\text { no }\end{array}$ & $\begin{array}{l}53 \% \\
47 \%\end{array}$ & $\begin{array}{l}34 \% \\
66 \%\end{array}$ \\
\hline $\begin{array}{l}\text { Internet users } \\
(p<0.001 *)\end{array}$ & $\begin{array}{l}\text { yes } \\
\text { no }\end{array}$ & $\begin{array}{l}54 \% \\
46 \% \\
\end{array}$ & $\begin{array}{l}33 \% \\
67 \% \\
\end{array}$ \\
\hline $\begin{array}{l}\text { Foreign languages } \\
(p=0.317)\end{array}$ & $\begin{array}{l}\text { yes } \\
\text { no }\end{array}$ & $\begin{array}{l}13 \% \\
87 \%\end{array}$ & $\begin{array}{l}11 \% \\
89 \%\end{array}$ \\
\hline $\begin{array}{l}\text { WWI (range of the Internet } \\
\text { usage) }\left(p<0.001^{*}\right)\end{array}$ & $\begin{array}{l}\text { mean }(\mathrm{M}) \\
\text { median }(\mathrm{Me})\end{array}$ & $\begin{array}{l}6.3 \\
2.0\end{array}$ & $\begin{array}{l}4.1 \\
0.0\end{array}$ \\
\hline $\begin{array}{l}\text { Social networks } \\
\left(p<0.001^{*}\right)\end{array}$ & $\begin{array}{l}\text { mean }(\mathrm{M}) \\
\text { median }(\mathrm{Me})\end{array}$ & $\begin{array}{l}18.6 \\
14.0\end{array}$ & $\begin{array}{l}16.5 \\
12.0\end{array}$ \\
\hline
\end{tabular}

$p$ - probability in the chi-squared test of independence, the Mann-Whitney test or the Student $t$-test; $*$ - differences statistically significant $(\alpha=0.05)$.

Source: own calculations based on the (Social Diagnosis, 2015), individual data.

in the case of the inactive ones, these indicators reach, respectively, $\mathrm{M}=4.1$ and $\mathrm{Me}=0$ ). However, there are no significant differences in terms of knowledge of foreign languages and having a driving license. Similarly to human capital, social capital is also higher for people with disabilities aged 50-64 who are economically active - the average number of people they keep in touch with is $18.8(\mathrm{Me}=14)$ while for economically inactive people $\mathrm{M}=16.5$, and $\mathrm{Me}=12$ (Table 2).

\section{Determinants of economic activity of Poles aged 50-64 - comparison of people with and without disabilities}

In the case of the population with disabilities aged 50-64, as indicated in the previous paragraph, the differences between economically active and inactive people do not yet indicate that these factors affect the economic activity of people from this 
subpopulation. In order to indicate these factors (ceteris paribus), a logistic regression equation was constructed. In addition, an analysis for people without disabilities was carried out (Table 3 ).

Table 3. Individual factors of extending the working life of Poles aged 50-64 - comparison of people with and without disabilities

\begin{tabular}{|c|c|c|c|c|c|c|c|c|}
\hline \multirow{2}{*}{ Variables } & \multicolumn{4}{|c|}{ People with disabilities } & \multicolumn{4}{|c|}{ People without disabilities } \\
\hline & $B$ & $S(B)$ & $P$ & OR & $B$ & $S(B)$ & $p$ & $O R$ \\
\hline Gender $^{\mathrm{a}}$ & & & & & 0.876 & 0.080 & $<0.001^{*}$ & 2.401 \\
\hline $\begin{array}{l}\text { The size of the place } \\
\text { of residence }\end{array}$ & & & & & & & $<0.001^{*}$ & \\
\hline small or medium & & & & & & & & \\
\hline town & & & & & -0.429 & 0.082 & 0.000 & 0.651 \\
\hline the city & & & & & -0.215 & 0.094 & 0.022 & 0.806 \\
\hline Having children ${ }^{c}$ & 0.399 & 0.188 & $0.034 *$ & 1.491 & 0.613 & 0.074 & $<0.001^{*}$ & 1.845 \\
\hline Care responsibilities $^{\mathrm{d}}$ & & & & & -0.461 & 0.097 & $<0.001^{*}$ & 0.630 \\
\hline Level of education ${ }^{\mathrm{e}}$ & & & $0.025^{*}$ & & & & $<0.001 *$ & \\
\hline $\begin{array}{l}\text { lower secondary } \\
\text { or below }\end{array}$ & -0.190 & 0.382 & 0.619 & 0.827 & -0.620 & 0.154 & 0.000 & 0.538 \\
\hline vocational & -0.017 & 0.349 & 0.960 & 0.983 & -0.288 & 0.129 & 0.025 & 0.750 \\
\hline secondary & -0.633 & 0.344 & 0.065 & 0.531 & -0.281 & 0.116 & 0.016 & 0.755 \\
\hline Educational activity ${ }^{\mathrm{f}}$ & 1.738 & 0.445 & $<0.001^{*}$ & 5.684 & 1.443 & 0.239 & $<0.001^{*}$ & 4.231 \\
\hline Computer users ${ }^{\mathrm{g}}$ & & & & & 0.313 & 0.091 & 0.001 & 1.368 \\
\hline Internet users ${ }^{\mathrm{h}}$ & 0.834 & 0.185 & $<0.001 *$ & 2.302 & & & & \\
\hline WWI & & & & & 0.020 & 0.004 & 0.000 & 1.020 \\
\hline Driving licence $^{\mathrm{i}}$ & & & & & 0.240 & 0.080 & 0.003 & 1.272 \\
\hline Const & -1.555 & 0.352 & 0.000 & 0.211 & 0.210 & 0.144 & 0.143 & 1.234 \\
\hline $\begin{array}{l}p \text { in the omnibus test } \\
\text { of model coefficients }\end{array}$ & \multicolumn{4}{|c|}{$\chi^{2}(12)=57.2 ; p<0.001^{*}$} & \multicolumn{4}{|c|}{$\chi^{2}(12)=631.3 ; p<0.001^{*}$} \\
\hline Nagerkelke's $R^{2}$ & \multicolumn{4}{|c|}{0.093} & \multicolumn{4}{|c|}{0.179} \\
\hline $\begin{array}{l}\% \text { of the correct } \\
\text { classifications } \\
\text { for } y=1\end{array}$ & \multicolumn{4}{|c|}{$65.4 \%$} & \multicolumn{4}{|c|}{$57.9 \%$} \\
\hline Count $R^{2}$ & \multicolumn{4}{|c|}{$59.0 \%$} & \multicolumn{4}{|c|}{$63.4 \%$} \\
\hline
\end{tabular}

$B$ - regression coefficient, $S(B)$ - error of $\beta$ estimation.

Reference groups: ${ }^{\mathrm{a}}$ women, ${ }^{\mathrm{b}}$ rural areas, ${ }^{\mathrm{c}, \mathrm{d}, \mathrm{f}, \mathrm{g}, \mathrm{h}, \mathrm{i}}$ no, ${ }^{\mathrm{e}}$ tertiary.

Source: own calculations based on the Social Diagnosis 2015, individual data.

The analysis confirms that human capital is the key factor in the growth of individual productivity. It has a vital role in maintaining the economic activity, and it 
is very important both for people with disabilities and others. However, a full list of determinants of extending working life for people with disabilities is different than for others, in the case of Poles with disabilities (aged 50-64), human capital measures are statistically significant determinants, while for people without disabilities, the list of factors behind the extension of working life is more detailed. What is more, factors related to the family situation (having children, care responsibilities), as well as gender and place of residence, play a much more significant role. The study confirms, ceteris paribus, the importance of human capital as the key factor behind economic activity.

For people with disabilities, the higher the level of education, the higher the probability of economic activity. This probability is approximately six times higher in the case of individuals with disabilities who are educationally active (in the last two years), and over two times higher for people with disabilities who know how to use the Internet. Additionally, people with children have a 1.5 times higher probability of economic activity than people with disabilities who are not parents.

Regarding people without disabilities, the following also have a statistically significant role for extending working life:

- gender (probability of economic activity is over two times higher in men than in women),

- place of residence (in comparison with rural areas, the probability is lower for city residents),

- and care duties (people who have to care about others are less economically active). The opportunities for economic activity are also higher for people who are computer literate, who have a driving licence, and is directly related to their Internet skills.

In the case of both populations, language skills as well as social capital, do not appear to be significant variables from the viewpoint of extending working life.

As noted in the earlier part of this paper, the population of people with disabilities is heterogeneous from the economic activity perspective. If one takes into consideration the level of disability, it can be seen that in the population with disabilities with a mild level of disability, the percentage of those economically active equals $29.3 \%$, with the moderate level $-23.2 \%$, and with severe level $-10.7 \%$. These three groups differ also from the perspective of the determinants of extending working life (Table 4).

For the population with a severe level of disability, only the level of education and computer usage are the significant factors (among listed in earlier models) of economic activity people aged 50-64. In comparison to the people with disabilities aged 50-64 with tertiary education, all other groups have a lower probability of economic activity. If a person with a severe level of disability can operate a computer, their probability of success (economic activity) is around five times higher (in comparison with people without this skill). Digital skills are a significant factor of being economically active also for people with a moderate level of disability - 
Table 4. Individual factors of extending the working life of Poles aged 50-64 by the level of disability

\begin{tabular}{|c|c|c|c|c|c|c|c|c|c|}
\hline \multirow{2}{*}{ Variables } & \multicolumn{3}{|c|}{ Mild } & \multicolumn{3}{|c|}{ Moderate } & \multicolumn{3}{|c|}{ Severe } \\
\hline & $B$ & $P$ & $O R$ & $B$ & $p$ & $O R$ & $B$ & $p$ & $O R$ \\
\hline $\begin{array}{l}\text { The size of the } \\
\text { place of residence }\end{array}$ & & $0.004 *$ & & & & & & & \\
\hline $\begin{array}{l}\text { small or medium } \\
\text { town }\end{array}$ & 1.323 & $0.001 *$ & 3.754 & & & & & & \\
\hline the city & 1.068 & $0.022 *$ & 2.909 & & & & & & \\
\hline Having children ${ }^{\mathrm{b}}$ & 1.535 & $<0.001 *$ & 4.643 & & & & & & \\
\hline Level of education ${ }^{c}$ & & $0.004 *$ & & & & & & $0.034 *$ & \\
\hline $\begin{array}{l}\text { lower secondary } \\
\text { or below }\end{array}$ & -0.239 & 0.806 & 0.788 & & & & -1.247 & 0.214 & 0.287 \\
\hline vocational & -0.074 & 0.937 & 0.928 & & & & -1.537 & 0.033 & 0.215 \\
\hline secondary & -1.718 & 0.070 & 0.179 & & & & -2.185 & 0.006 & 0.112 \\
\hline Computer users ${ }^{\mathrm{d}}$ & & & & & & & 1.587 & $0.024 *$ & 4.888 \\
\hline Internet users ${ }^{\mathrm{e}}$ & 2.447 & $<0.001 *$ & 11.559 & & & & & & \\
\hline WWI & -0.088 & $0.001 *$ & 0.916 & 0.036 & $0.003 *$ & 1.036 & & & \\
\hline Const & -2.337 & $0.016^{*}$ & 0.097 & -1.389 & $<0.001 *$ & 0.249 & -1.712 & $0.033^{*}$ & 0.181 \\
\hline $\begin{array}{l}p \text { in the omnibus } \\
\text { test of model } \\
\text { coefficients }\end{array}$ & $\chi^{2}(8)=$ & $72.54 ; p<$ & $0.001 *$ & $\chi^{2}(1)$ & $8.5 ; p=$ & $.004 *$ & & $\begin{array}{l}(12)=1 \\
=0.00\end{array}$ & \\
\hline Nagerkelke's $R^{2}$ & & 0.365 & & & 0.029 & & & 0.174 & \\
\hline $\begin{array}{l}\% \text { of the correct } \\
\text { classifications for } \\
y=1\end{array}$ & & $78.4 \%$ & & & $31.2 \%$ & & & $59.5 \%$ & \\
\hline Count $R^{2}$ & & $72.7 \%$ & & & $73.7 \%$ & & & $76.8 \%$ & \\
\hline
\end{tabular}

$B$ - regression coefficient. Reference groups: ${ }^{\mathrm{a}}$ rural area, ${ }^{\mathrm{b}, \mathrm{d}, \mathrm{e}}$ no, ${ }^{\mathrm{c}}$ tertiary.

Source: own calculations based on the (Social Diagnosis, 2015), individual data.

the WWI variable, measured their progress in Internet usage, is positively related with the possibilities of economic activity (there is only one significant variable). Similarly, for people with a mild level of disability, Internet usage is important for being economically active. This probability is also higher for people from this group who have children (around 4.5 times higher), with tertiary education (in comparison with others) and living in cities (around 3-4 times higher than people with disabilities aged 50-64 in rural areas). 


\section{Final remarks}

Stimulating the economic activity of the older generation is one of the most important tasks of contemporary social policy. The Polish population, just like the populations of other European countries, is getting older. This situation is similar in each region and the degree of dissimilarity between regions is decreasing (Walesiak and Dehnel, 2019). Population ageing, together with the simultaneous increase in the average life span and improvement in the quality of life (including older people), increase the focus on actions aimed at extending people's working life and delaying the decision to retire. Taking into consideration that older people who lead a healthy life can still be productive (Trzpiot and Szoltysek, 2017) - not only in the social but also in the economic sense - this approach has a growing importance. Compared to other EU members, Poland is one of the countries with the lowest employment indicators for older age groups, which makes such actions even more necessary. Among the actions aimed at extending people's working life, the most important are those related to lifelong learning, targeted at improving the competencies. Since human capital is a key factor in the growth of individual productivity, its role in maintaining economic activity is indisputable - both for people with disabilities and others. However, in the case of persons with disabilities, the list of measures of human capital is shorter than for those without, for example, computer skills and driving licence are less important for people with disabilities. On the other hand, social capital does not appear to be a significant factor for extending the working life both for those with and without disabilities (on each level of disability). The differences between the determinants of economic activity in groups with different levels of disability are expected. Similarly, the significance of digital skills for economic activity was expected. Nowadays, in digitalised workplaces, this factor is significant for all workers. However, for people with disabilities, especially with huge mobility problems, the competencies related to computer and Internet usage can 'open the door' to activity, and this tendency has been important for some years and will gain importance in the future.

A limitation of this research can be the fact that the Social Diagnosis data refers to the year 2015. These data regard the situation from five years ago, which in the context of the economic activity of people aged 50+ is particularly important. The economic activity of the total population aged 50+ is growing. For approximately ten years in Poland, various actions aimed at increasing economic activity have been undertaken, and they reduce 'pushing out' from the labour market, however this impact is lower for older Poles with disabilities. In light of the LFS data, at the end of 2018 the percentage of economically active people within the population of Poles with disabilities (in total) was 17.2, in $2017-16.4 \%$, in $2016-15.7 \%$ and 2015 - $16.9 \%$ (GUS, 2019, 2017). Thus, this indicator is stable and in 2018 remained at a similar level as in 2015. Additionally, the structure of people with disabilities by the level of disability is stable - in the population of those economically active the share of people with severe level of disabilities is $8-9 \%$, with moderate level - 
approximately $50 \%$, and with mild level - approximately $40 \%$. The share of people who are inactive due to disability and illness is also stable - about 13\% (Główny Urząd Statystyczny [GUS], 2017, 2019). These data do not refer to people aged 50-64 but it could be supposed that in this population the tendency is similar. Thus it could be concluded that the impact of social policy measures is still low and does not influence the increase of economic activity of Poles with disabilities on a significant scale.

\section{References}

Aaron, H. J. and Callan, J. M. (2011). Who retires early? (Center for Retirement Research Working Paper 2011-10). Boston: Boston College.

Barnes, H., Parry, J., and Taylor, R. (2004). Working after state pension age: Qualitative research. (Department for Work and Pensions (DWP) Research Report No. 208), London: DWP.

Clark, R. L., Ogawa, N., Lee, S.-H., and Matsukura, R. (2008). Older workers and national productivity in Japan. Population and Development Review, 34(Supplement), 257-274.

Coile, C. C. (2004). Retirement incentives and couples' retirement decisions. The B.E. Journal of Economic Analysis \& Policy, De Gruyter, 4(1), 1-30.

Contreras, N., Martellucci E., and Thum, A.-E. (2013). Extending working life in Belgium (CEPS Working Document, No. 386).

De Baets, S. and Warmoes, V. (2012). Learning later in life: The older worker's perspective. In Working and ageing. The benefits of investing in an ageing workforce (pp. 134-154). Luxembourg: Cedefop.

De Preter, H., Van Looy, D., and Mortelmans, D. (2013). Individual and institutional push and pull factors as predictors of retirement timing in Europe: A multilevel analysis. Journal of Aging Studies, 27, 299-307.

Droogenbroeck, F. van and Spruyt, B. (2014). To stop or not to stop: An empirical assessment of the determinants of early retirement among active and retired senior teachers. Research on Aging, 36(6), 753-777.

Funk, L. (2004). Employment opportunities for older workers: A comparison of selected OECD countries (DICE Research Report).

Główny Urząd Statystyczny [GUS]. (2017). Rocznik Statystyczny Pracy 2017. Warszawa: Główny Urząd Statystyczny.

Główny Urząd Statystyczny [GUS]. (2019). Rocznik Statystyczny Pracy 2019. Warszawa: Główny Urząd Statystyczny.

Gruszczyński, M. (Ed.). (2012), Mikroekonometria. Modele i metody analizy danych indywidualnych. Warszawa: Oficyna a Wolters Kluwer business.

Guria, A. (2008). Living longer, working longer. The Journal AARP International.

Gustman, A. L. and Steinmeier, T. L. (2005). The social security early entitlement age in a structural model of retirement and wealth. Journal of Public Economics, 89(2-3), 441-463.

Hashim, J. and Wok, S. (2011). Competence as a moderator of older workers' trainability and performance. Department of Business Administration, Economics \& Management Sciences, International Islamic University Malaysia, 1-22. Retrieved November 12, 2020 from https://www.ufhrd.co.uk/ wordpress/wp-content/uploads/2013/10/Hashim-Wok-full-paper.pdf

Hofäcker, D. (2015). In line or at odds with active ageing policies? Exploring patterns of retirement preferences in Europe. Ageing and Society, 35(7), 1529-1556. 
Hosmer, D. W. Jr., Lemeshow, S., and Sturdivant, R. X. (2013). Applied logistic regression. New Jersey: John Wiley \& Sons Inc.

Humphrey, A., Costigan, P., Pickering, K., Stratford, N., and Barnes, M. (2003). Factors affecting the labour market participation of older workers. (Department of Work and Pension, Research Report No. 200). London.

Jurek, Ł. (2012). Ekonomia starzejącego się społeczeństwa. Warszawa: Difin.

Khan, M. R., Rutledge, M. S., and Wu, A. Y. (2014). How do subjective longevity expectations influence retirement plans? (Working Paper 2014-01). Chestnut Hill, MA: Center for Retirement Research at Boston College.

Kołodziejczak, W. (2018). Criteria used in the LFS to identify the population's economic activity status vs. the respondent's subjective views: Implications for unemployment research. Econometrics, 22(3), 99-113.

Kryńska, E., Krzyszkowski, J., Urbaniak, B., and Wiktorowicz, J. (Eds.). (2013). Diagnosis of the current situation of women and men aged 50+ on the labour market in Poland. Lodz: University of Lodz.

Krzyżowski, Ł. (2011). Strategie przechodzenia na emeryturę w Polsce po 1989 roku. Oczekiwania społeczne i praktyki kulturowe. Studia Socjologiczne, 2(201), 165-189.

Lis, M., and Magda, I. (2014). Dynamika płac w cyklu życia a indywidualny stan zdrowia. Gospodarka Narodowa, 4(272), 121-142.

Maddala, G. S. (1983). Limited-dependent and qualitative variables in econometrics. Cambridge: Cambridge University Press.

Maltby, T. (2011). Extending working lives? Employability, work ability and better quality working lives. Social Policy and Society, 10(3), 299-308.

McNair, S., Flynn, M., Owen, L., Humphreys, C., and Woodfield, S. (2004). Changing work in later life: A study of job transitions. Surrey: Centre for Research into the Older Workforce, University of Surrey.

Menard, S. (2002). Applied logistic regression analysis Sage Papers Series on Quantitative Applications in the Social Sciences, series no 07-106.

Naegele, G. and Bauknecht, J. (2013). WP3: Conceptual framework. Task 1 of wp3. Retrieved May 15, 2015 from http://mopact.group.shef.ac.uk/wp-content/uploads/2013/10/D3.1-Extending-working-lives-conceptual-framework.pdf

Oorschot, W. van and Jensen, P. H. (2009). Early retirement differences between Denmark and The Netherlands. A cross-national comparison of push and pull factors in two small European welfare states. Journal of Aging Studies, 23(4), 267-278.

Paxton, P. (1999). Is social capital declining in the United States? A multiple indicator assessment. American Journal of Sociology, 105(1), 88-127.

Phillipson, Ch. and Smith, A. (2005). Extending working life: A review of the research literature. (Department for Work and Pension, Research Report No. 299), London.

Silcock, D. (2013). Extending working lives. Pensions, 17, 229-235.

Sinclair, D., Watson, J., and Beach, B. (2013), Working longer: An EU perspective. ILC-UK. Retrieved April, 4, 2014 from https://ilcuk.org.uk/wp-content/uploads/2018/10/EU-Member-State-profiles_ Working-Longer-An-EU-Persepctive.pdf

Smeaton, D. and McKay, S. (2003). Working after state pension age: Quantitative analysis. (Department for Work and Pensions, Research Report No. 182), London.

Social Diagnosis. (2015). Database. Retrieved from http://www.diagnoza.com/index-en.html

Solinge, H. van and Henkens, K. (2007). Involuntary retirement: The role of restrictive circumstances, timing, and social embeddedness. Journals of Gerontology: Social Sciences, 62B(5), S295-S303.

Stone, W., Gray M., and Hughes, J. (2003). Social capital at work: How family, friends and civic ties relate to labour market outcomes. Australian Institute of Family Studies, Research Paper, (31). 
Sweet, S. A. and Grace-Martin, K. (2003). Data analysis with SPSS. A first course in applied statistics. Boston: Allyn and Bacon.

Szymczak, W. (2010). Podstawy statystyki dla psychologów. Warszawa: Difin.

Trzpiot, G. and Szołtysek, J. (2017). Starzenie się funkcjonalnych grup wieku a kapitał społeczny. Econometrics, 2(56), 9-27.

Walesiak, M. and Dehnel, G. (2019). Assessment of changes in population ageing of Polish provinces in 2002, 2010 and 2017 using the hybrid approach. Econometrics, 23(4), 1-15.

Walker, A. (1985). Early retirement: Release or refuge from the labour market?. The Quarterly Journal of Social Affairs, 1(3), 211-229.

Whiting, E. (2005). The labour market participation of older people. Labour Market Trends, 113, 285-296 .

Wiktorowicz, J. (2014). Wydłużenie aktywności zawodowej czy przejście na emeryturę? Studium mikroekonomiczne. Studia Demograficzne, 2(166), 7-36.

Wiktorowicz, J. (2016). Międzypokoleniowy transfer wiedzy a wydlużanie okresu aktywności zawodowej. Łódź: Wydawnictwo Uniwersytetu Łódzkiego.

Zwick, T. (2012). Consequences of seniority wages on the employment structure. Industrial \& Labor Relations Review, 65(1), 108-125.

\section{INDYWIDUALNE CZYNNIKI WYDLUŻAJĄCE OKRES AKTYWNOŚCI ZAWODOWEJ OSÓB NIEPELNOSPRAWNYCH W POLSCE}

Streszczenie: Wydłużanie okresu aktywności zawodowej stanowi istotne wyzwanie współczesnych gospodarek. W Polsce 40\% osób w wieku 50-64 lata jest nieaktywnych zawodowo. W populacji osób z niepełnosprawnościami odsetek ten jest znacznie wyższy (78\%). Celem opracowania jest ocena indywidualnych uwarunkowań aktywności zawodowej Polaków w wieku 50-64 lata i porównanie tych czynników w populacji osób z niepełnosprawnościami względem pozostałych. Analiza empiryczna oparta została na danych indywidualnych Diagnozy Społecznej (dla osób w wieku 50-64 lata). Badanie przeprowadzone zostało z wykorzystaniem regresji logistycznej, jak również testu t-Studenta, testu Manna-Whitneya i testu niezależności chi-kwadrat. Wyniki analiz z zastosowaniem regresji logistycznej wskazują, że uwarunkowania wydłużania okresu aktywności zawodowej w przypadku osób z niepełnosprawnościami są inne niż dla pozostałych - statystycznie istotne czynniki to w ich przypadku formalne rezultaty rozwoju kapitału ludzkiego, podczas gdy w przypadku osób bez niepełnosprawności lista tych czynników jest znacznie dłuższa.

Słowa kluczowe: aktywność ekonomiczna, wydłużanie okresu aktywności zawodowej, niepełnosprawność, regresja logistyczna. 